\title{
PAKOM PETERNAK PUYUH DESA GAJAHAN COLOMADU KARANGANYAR
}

\author{
Lukman Hakim $^{1}$, Dedi Hanwar ${ }^{2}$, Eko Sugiyanto $^{1}$, dan Zulfa Irawati ${ }^{1}$ \\ ${ }^{1}$ Fakultas Ekonomi dan Bisnis \\ ${ }^{2}$ Fakultas Farmasi \\ Universitas Muhammadiyah Surakarta \\ lukman_hakim@ums.ac.id
}

\begin{abstract}
The purpose of this activity is improving knowledge and skill of quail farmer's in waste management of quail. The management of waste is processing of organic fertilizer. The participate in the activity are quail farmer's in RWII Sub-village Ginung, Gajahan Village, Colomadu, Karanganyar. The result of this activity in step I that is be good attention from a quail farmer's especiality at trainning time process of product organic fertilizer. As for its result as follows; trainning and assistence quail farmer's is followed enthusiastic fully by participant and greeted positive by head of Village Gajahan Colomadu, Karanganyar. That are many question in trainning process of product organic fertilizer. The others result in activity is a quail farmer's started processing of product organic fertilizer in housebreed themselves. The processing of product organic fertilizer will be clean in Gajahan Village environment and also this activity will be value added toward income quail farmer's.
\end{abstract}

Kata kunci: Manajemen limbah, lingkungan bersih, pendapatan peternak bertambah

\section{PENDAHULUAN}

Para peternak saat ini ummnya menganggap bahwa semua limbah itu tidak ada gunanya, kotor dan menjijikan sehingga harus dibuang atau dilenyapkan dari lokasi peternakan. Apapun caranya yang penting limbah ternak tidak terlihat lagi. Banyak peternak kemudian membuang limbah di tempat yang jauh dari lokasi pemukiman dengan menghanyutkan di sungai kecil atau selokan yang mengalir di sekitar desanya, mengubur di dalam tanah atau membakarnya setelah kering. Proses pembuangan seperti demikian sangatlah tidak efektif bahkan berdampak negatif seperti mencemari lingkungan, polusi udara yang buruk dan lainnya.

Kasus yang terjadi tentang pembuangan kotoran sapi di tepi jalan areal persawahan yang terjadi di daerah Boyolali Jawa Tengah sangat memprihatinkan (Suara merdeka, 23 Desember 2009). Entah pemikiran apa yang menghinggapi peternak, sehingga mudah membuang kotoran ini pada areal terbuka dengan seenaknya. Selain menimbulkan bau yang tidak sedap dan pandangan mata yang buruk, juga mengakibatkan terjadinya sumber penyakit. Namun secara pasti, kotoran ini dibuang oleh pemilik peternakan tersebut memang tersebar luas disekitar daerah Boyolali. 
Sesungguhnya akar masalah pembuangan limbah ini terjadi akibat dari proses produksi terus-menerus tanpa memiliki konsep pengelolaan pembuangan yang baik. Cara instant untuk menyelesaikan masalah justru menimbulkan masalah baru yang lebih berdampak luas. Sistem kandang longyam pada ayam sebenarnya bisa menjadi solusi bagi para peternak puyuh. Sistem ini merupakan sistem terpadu yang memadukan usaha peternakan dengan perikanan. Kotoran dan sisa pakan ternak yang tercecer akan jatuh kebawah sehingga berfungsi sebagai makanan bagi usaha perikanan. Dan dijadikan makan. Namun sayang, karena biaya yang dibutuhkan untuk membangun sistem ini tidak sedikit sehingga menjadi kendala bagi peternak dengan modal yang terbatas.

Desa Gajahan yang termasuk wilayah Kabupaten Karanganyar adalah salah satu desa di Kabupaten yang mempunyai potensi peternakan puyuh untuk dikembangkan menjadi sektor andalan di Jateng. Namun dibalik potensi ekonomi Desa Gajahan yang potensial, tetapi juga ada perilaku buruk dari sebagian peternak yang kurang disiplin dalam pembuangan kotoran/limbah ternak. Mereka dengan enaknya membuang limbah ternak di selokan desa Gajahan tersebut.

Terkait proses pembuangan kotoran secara langsung, pemrosesan awal sebenarnya sangat diperlukan untuk mengurangi dampak negatif yang terjadi. Tetapi nampaknya hal ini enggan dilakukan selain memberikan tambahan pekerjaan bagi para peternak juga mengakibatkan pembengkakan untuk ongkos pembuangan. Sehingga yang dilakukan adalah pembuangan secara sepihak tanpa memikirkan dampak yang akan terjadi.

Ide untuk membuang kotoran di tepi selokan areal persawahan mungkin bukan merupakan ide yang cukup buruk. Peternak berasumsi kotoran ini akan bermanfaat bagi para petani sebagai pupuk organik. Padahal kotoran yang belum diproses (pengomposan) justru berakibat kurang baik bagi tanaman itu sendiri. Hal ini diakibatkan masih tersimpannya gas-gas yang tersimpan dalam kotoran dan keluar saat terjadi pengomposan baik anaerob maupun aerob.

Melihat berbagai persoalan tersebut diatas, menggugah semangat dan mendorong peternak Desa Gajahan Colomadu untuk mencari solusi mudah, tepat murah dan berfaedah dalam mengelola limbah ternak puyuh. Pengelolaan limbah dapat dinlai tepat apabila : (1) Dapat dilakukan oleh peternak itu sendiri (mandiri), (2) Dapat memberikan keuntungan nyata bagi peternak (produktif), (3) Dapat menyelesaikan semua jenis dan masalah limbah ternak puyuh (komprehensif), (4) Tidak mencemari lingkungan dan udara.

Dalam rangka mencari penyelesaian masalah limbah secara tepat dan memberikan efek dan manfaat pemberdayaan bagi peternak yang kurang mampu di lingkungan Desa Gajahan, maka sistem pengelolaan limbah terpadu, mandiri dan produktif berbasis peternak akan dilaksanakan. Dari kegiatan tersebut diharapkan bahwa semua limbah dapat dimanfaatkan atau bernilai ekonomis setelah dilakukan pemprosesan. Apabila limbah ternak yang dihasilkan dari setiap peternak kemudian diproses menjadi pupuk organik, selanjutnya dipasarkan, maka uang dari hasil penjualan pupuk organik tersebut dapat digunakan untuk membayar tenaga kerja pemrosesan dan terutama meningkatkan pendapatan para peternak puyuh.

Secara keseluruhan kegiatan pemberdayaan peternak berbasis pengelolaan limbah mandiri dapat dirumuskan : (1) Permasalahan pengelolaan limbah dapat diselesaikan dengan sistem pengelolaan limbah terpadu, mandiri dan produktif berbasis peternak. (2) Sistem pengelolaan limbah secara terpadu, mandiri dan produktif dapat dimanfaatkan untuk peningkatan 
kesejahteraan dan pemberdayaan peternak lemah (gurem) sebagai tenaga pelaksana dan menjadi sumber penghasilan bagi peternak. (3) Sistem pengelolaan limbah ternak secara mandiri dan produktif dapat digunakan sebagai model dalam pemecahan masalah limbah peternakan dan lingkungan dan juga bermanfaat dari segi ekonomis. (4) Pengembangan sistem pengelolaan limbah yang benar dan produktif dapat menjadikan petani sekitar Desa Gajahan mudah mendapatkan pupuk organik murah dan kualitas baik (standar).

Permasalahan dari pengabdian ini adalah kurangnya kesadaran para peternak puyuh dalam membuang limbah dan juga kurangnya pemahaman peternak dalam mengelola limbah puyuh agar supaya menjadi produk yang lebih bermanfaat, yaitu produk pupuk organik.

1. Pengertian Manajemen

Dari segi istilah atau pemahaman, manajemen dapat sebagai Ilmu, sebagai seni, atau sebagai proses. Manajemen sebagai ilmu, menurut Luther Gullick mendefinisikan manajemen sebagai suatu bidang ilmu pengetahuan (science) yang berusaha secara sistematis untuk memahami mengapa dan bagaimana manusia bekerja bersama untuk mencapai tujuan dan membuat sistem kerjasama ini bermanfaat bagi kemanusiaan. Manajemen memerlukan disiplin ilmu pengetahuan lain dalam penerapannya misal ilmu ekonomi (Makroekonomi, Mikroekonomi), Matematik/statistik, akuntansi dan sebagainya. Manajemen juga melahirkan disiplin ilmu yang mempunyai karakteristik sendiri, antara lain: Manajemen Keuangan, Manajemen Pemasaran, Manajemen SDM, Manajemen Operasional dan Manajemen Perilaku.

Manajemen sebagai "proses" yaitu proses pengkoordinasian berbagai aktifitas pekerjaan dan pengalokasian sumber daya (6M), melalui bantuan dan kerjasama dengan orang lain sehingga pekerjaan tersebut dapat terselesaikan secara efisien dan efektif. Efisien adalah memperoleh output terbesar dengan input yang tertentu, digambarkan sebagai "melakukan segala sesuatu secara benar/doing things right". Efektif adalah menyelesaikan kegiatankegiatan sehingga sasaran organisasi dapat tercapai.

Manajemen sebagai "proses", juga bisa berkaitan dengan fungsi-fungsi manajemen, yaitu : "Management is a distinct process consisting of planning, organizing, actuating/coordinating, controlling, utilizing in each both science and art and follow in order to accomplish predetermined objectives." Manajemen adalah proses yang khas terdiri dari tindakan perencanaan, pengorganisasian, pelaksanaan dan pengendalian dimana dalam masing-masing bidang tersebut digunakan ilmu pengetahuan \& keahlian yang diikuti secara berurutan dalam usaha mencapai sasaran \& tujuan yang telah ditetapkan.

Manajemen sebagai "seni", menurut Luther Gullick: "Management is the art of securing maximum result with minimum of efforts as to secure maximum prosperity and happiness for both employer and employee and give the public the best possible services". Manajemen adalah seni untuk mencapai hasil yang maksimal dengan usaha yang minimal, demikian pula mencapai kesejahteraan dan kebahagiaan maksimal bagi pimpinan maupun pekerja serta memberikan pelayanan yang sebaik mungkin kepada masyarakat/ konsumen.

Manajemen sebagai "profesi" merupakan suatu bidang pekerjaan yang dilakukan oleh orang-orang yang memiliki keahlian dan ketrampilan sebagai kader, pemimpin atau 'manajer' pada suatu organisasi/perusahaan tertentu. Profesi 'manajer' merupakan sebuah profesi atau jabatan spesifik dan 'prestigious' sebagai 'decision maker' yang dapat menentukan 
berkembangnya suatu organisasi/perusahaan dimasa mendatang.

\section{Fungsi Operasional Manajemen}

Fungsi operasional atau jenis-jenis manajemen antara lain :

a. Manajemen Sumber Daya Manusia Manajemen Sumber Daya Manusia adalah penerapan manajemen berdasarkan fungsinya untuk memperoleh sumber daya manusia yang terbaik bagi bisnis yang kita jalankan dan bagaimana sumber daya manusia yang terbaik tersebut dapat dipelihara dan tetap bekerja bersama kita dengan kualitas pekerjaan yang senantiasa konstan ataupun bertambah.

b. Manajemen Pemasaran

Manajemen Pemasaran adalah kegiatan manajemen berdasarkan fungsinya yang pada intinya berusaha untuk mengidentifikasi apa sesungguhnya yang dibutuhkan oleh konsumen, dana bagaimana cara pemenuhannya dapat diwujudkan .

c. Manajemen Produksi

Manajemen Produksi adalah penerapan manajemen berdasarkan fungsinya untuk menghasilkan produk yang sesuai dengan standar yang ditetapkan berdasarkan keinginan konsumen, dengan teknik produksi yang seefisien mungkin, dari mulai pilihan lokasi produksi hingga produk akhir yang dihasilkan dalam proses produksi.

d. Manajemen Keuangan

Manajemen Keuangan adalah kegiatan manajemen berdasarkan fungsinya yang pada intinya berusaha untuk memastikan bahwa kegiatan bisnis yang dilakukan mampu mencapai tujuannya secara ekonomis yaitu diukur berdasarkan profit. Tugas manajemen keuangan diantaranya merencanakan dari mana pembiayaan bisnis diperoleh, dan dengan cara bagaimana modal yang telah diperoleh dialokasikan secara tepat dalam kegiatan bisnis yang dijalankan

e. Manajemen Informasi

Manajemen Informasi adalah kegiatan manajemen berdasarkan fungsinya yang pada intinya berusaha memastikan bahwa bisnis yang dijalankan tetap mampu untuk terus bertahan dalam jangka panjang. Untuk memastikan itu manajemen informasi bertugas untuk menyediakan seluruh informasi yang terkait dengan kegiatan perusahaan baik informasi internal maupun eksternal, yang dapat mendorong kegiatan bisnis yang dijalankan tetap mampu beradaptasi dengan perubahan yang terjadi di masyarakat.

3. Manajemen Produksi

a. Pengertian Manajemen Produksi

Manajemen produksi merupakan kegiatan untuk mengatur dan mengkordinasikan penggunaan sumber-sumber daya yang berupa sumber daya manusia, sumber daya alat dan sumber daya dana serta bahan, secara efektif dan efisien, untuk menciptakan dan menambah kegunaan (utility) sesuatu barang atau jasa. Dari uraian di atas, dapatlah dinyatakan bahwa manajemen produksi dan operasi merupakan proses pencapaian sumber-sumber daya untuk memproduksi atau menghasilkan barang-barang atau jasa-jasa yang berguna sebagai usaha untuk mencapai tujuan dan sasaran organisasi. Sasaran dari organisasi itu antara lain adalah untuk mempeoleh tingkat laba tertentu atau memaksimalisasi laba, memberikan pelayanan dengan tingkat pelayanan yang baik, serta berupaya dan 
berusaha untuk menjamin eksistensi dari organisasi tersebut.

Ada dua permasalahan yang penting dalam peningkatan produktivitas, yaitu: (1) produktivitas baru meningkat bila terdapat peningkatan kondisi kerja dari kondisi yang kurang baik menjadi kondisi yang lebih baik. (2) beberapa hasil peningkatan produktivitas tidak dapat membantu organisasi secara keseluruhan, karena hasil tersebut hanya terkait dengan perbaikan pada bidang tertentu saja, sedangkan bidang yang lainnya mungkin tetap tidak terpengaruh. Manajer produksi dan operasi dalam mengatur dan mengkordinasikan penggunaan sumber-sumber daya, perlu membuat keputusan-keputusan yang berhubungan dengan usaha-usaha untuk mencapai tujuan, agar barangbarang dan jasa-jasa yang dihasilkan sesuai dan tepat dengan apa yang diharapkan, yaitu tepat mutu (kualitas), tepat jumlah (kuantitas) dan tepat waktu yang direncanakan, serta dengan biaya yang rendah.

Kesimpulannya bahwa Manajemen Produksi merupakan serangkaian proses dalam menciptakan barang dan jasa atau kegiatan mengubah bentuk dengan menciptakan atau menambah manfaat suatu barang dan jasa yang akan digunakan untuk memenuhi kebutuhan manusia. Secara history kegiatan operasi sudah dikenal beribu-ribu tahun yang lalu, sejak manusia mengenal cara berburu, membuat suatu benda, dan lain-lain. Pengetahuan atau cara tersebut berkembang terus dengan ditemukan prinsip serta metode baru, dan akhirnya terbentuk menjadi suatu ilmu sendiri, dilengkapi dengan masuknya unsur-unsur ilmu pengetahuan yang lain.

b. Fungsi dan Sistem Produksi

Manajemen Produksi dan Operasi tidak hanya manajemen pabrik manufaktur. Dalam pembahasan Manajemen Produksi dan Operasi, di samping menyangkut pembahasan organisasi pabrik manufaktur, juga menyangkut pembahasan organisasi jasa, seperti perbankan, rumah sakit dan jasa transportasi. Perusahaan atau organisasi jasa, pertumbuhannya sangat pesat, dan dari hasil-hasil penemuan dapatlah diketahui bahwa teknik-teknik Manajemen Produksi dan Operasi dapat dipergunakan secara efektif untuk mengurangi biaya dan memperbaiki hasil jasa yang ditawarkan atau dijual.

Dalam kegiatan produksi dan operasi tercakup seluruh proses yang mengubah masukan (input) dan menggunakan sumber-sumber daya untuk menghasilkan keluaran (output) yang berupa barang atau jasa. Dalam suatu kegiatan produksi dan operasi, Manajer Produksi dan Operasi harus mampu membina dan mengendalikan arus masukan (input) dan keluaran (output), serta mengelola penggunaan sumber-sumber daya yang dimiliki. Agar kegiatan dan fungsi produksi dan operasi dapat lebih efektif, maka para manajer harus mampu mendeteksi masalah-masalah penting serta mampu mengendalikan dan mengawai sumber-sumber daya yang sangat terbatas.

Manajer produksi dan operasi harus dapat merencanakan secara efektif penggunaan sumber-sumber daya yang sangat terbatas, memperkirakan dampak pada sasaran 
dan mengorganisasikan pengimplementasian dari rencana. Berdasarkan rencana yang disusun maka keputusan-keputusan yang lebih terinci harus dibuat, seperti besarnya partai (batch) dari produk untuk macam-macam yang berbeda, waktuwaktu lembur dan variabel-variabel tenaga kerja yang lain, prosedur pengendalian mutu, pemesanan bahan dan banyak prosedur-prosedur lain yang harus diterapkan atau diimplementasikan. Rencana tidak harus selalu diikuti ketidaktepatan peramalan atau prakiraan penjualan serta banyak alasan-alasan lain.

Ada empat fungsi terpenting dalam fungsi produksi dan operasi adalah: (1) Proses pengolahan, merupakan metode atau teknik yang digunakan untuk pengolalahan masukan (inputs). (2) Jasa-jasa penunjang, merupakan saran yang berupa pengorganisasian yang perlu untuk penetapan teknik dan metode yang akan dijalankan, sehingga proses pengolahan dapat dilaksanakan secara efektif dan efisien. (3) Perencanaan, merupakan penetapan keterkaitan dan pengorganisasian dari kegiatan produksi dan operasi yang akan dilakukan dalam suatu dasar waktu atau periode tertentu. (4) Pengendalian atau pengawasan, merupakan fungsi untuk menjamin terlasananya kegiatan sesuai dengan yang direncanakan, sehingga maksud dan tujuan untuk pengunaan dan pengolahan masukan (inputs) pada kenyataannya dapat dilaksanakan.

c. Sistem Pendukung Kegiatan Produksi

Manajer produksi dan operasi membuat keputusan-keputusan mengenai fungsi produksi dan operasi, serta sistem transformasi yang dipergunakan. Dari uraian ini terdapat tiga pengertian yang penting mendukung pelaksanaan kegiatan Manajemen Produksi dan Operasi yaitu fungsi, sistem dan keputusan.

Pertama, mengenai fungsi dapatlah dinyatakan bahwa manajer produksi dan operasi bertanggung jawab untuk mengelola bagian atau fungsi dalam organisasi yang menghasilkan barang atau jasa. Jadi istilah produksi dan operasi dipergunakan untuk menunjukkan fungsi yang menghasilkan barang atau jasa. Sehingga produksi atau operasi sama halnya dengan pemasaran dan keuangan atau pembelanjaan sebagai salah satu fungsi organisasi perusahaan dan merupakan salah satu fungsi bisnis.

Kedua, mengenai sistem, dalam hal ini terkait dengan perumusan sistem transformasi yang menghasilkan barang atau jasa. Pengertian sistem ini tidak hanya pada pemahaman produksi dan operasinya, tetapi yang lebih penting lagi adalah sebagai dasar untuk perancangan dan penganalisisan operasi produksi, yang terdapat dalam proses pengkonversian di dalam persahaan. Dalam hal kita berbicara tentang sistem keseluruhan dalam perusahaan, dimana terkait dengan bidang-bidang fungsi lain diluar produksi dan operasi.

Akhirnya, tentang keputusan, dimana unsur yang terpenting di dalam manajemen prosuksi dan operasi adalah pengambilan keputusan. Oleh karena seluruh manajer bertugas dan tidak terlepas dengan hal pengambilan keputusan, maka penekanan utama dalam pembahasan manajemen produksi dan operasi adalah proses pengambilan keputusan. 
Pengambilan keputusan dalam manajemen produksi dan operasi, terdapat di dalam proses, kapasitas, persediaan, tenaga kerja dan mutu.

\section{Proses Produksi Pupuk Organik Dari} Kotoran Puyuh

Kotoran puyuh, menjadi salah satu produksi dalam beternak disamping hasil telurnya. Bukan hanya manfaat telur puyuh saja yang dihasilkan, bahkan kotoran puyuh pun demikian bermanfaat dan berhasilguna. Seiring dengan berbagai himbauan mengenai penggunaan pupuk organik kompos dalam dunia pertanian, kotoran puyuh merupakan bahan pembuat pupuk yang luar biasa kandungannya demi untuk kesuburan. Dalam artikel-artikel terkait bisa disimak mengenai hal tersebut. Kemudian bagaimana pembuatan pupuk kompos pupuk organik dengan bahan kotoran puyuh?

Untuk hal pengolahan sampai pada komposisi bahan-bahannya, berikut ini akan di jelaskan bagaimana proses dan bahan membuat pupuk organik memakai kotoran puyuh. Proses pembuatan pupuk organik dari kotoran puyuh bisa diolah jadi kompos kualitas tinggi dengan menggunakan starter misalnya EM4, dimana cara buatnya di fermentasi dengan bantuan EM. Bahan-bahan antara lain:

a. 1 ton bahan organik 1 liter EM4

b. Kotoran puyuh $800 \mathrm{~kg}$

c. Dedak halus $100 \mathrm{~kg}$.

d. Bahan lain $100 \mathrm{~kg}$.

Proses pembuatannya sebagai berikut:

a. EM diencerkan dengan air 20 liter + Gula pasir $0.5 \mathrm{~kg} /$ molases. dan disiramkan ke kotoran puyuh.

b. Selanjutnya dilakukan pembalikan setiap pagi dan sore, atau pake starter degra ditabur langsung atau dengan starter lainnya seperti starbio dan lain lain.

Hasilnya berupa kompos jadi telah di uji kandungan zatnya pada balai besar pengujian tanah di bogor. telah di tayangkan pada blog Puyuh jaya beberapa hari lalu.

Tujuan yang diharapkan dari pelaksanaan pengabdian ini adalah pendampingan usaha kepada para peternak puyuh dalam mengelola limbah puyuh agar supaya menjadi produk yang lebih bermanfaat, yaitu produk pupuk organik. Dengan kegiatan pengelolaan limbah secara mandiri dan produktif ini, maka akan didapatkan manfaat ganda yaitu pemberdayaan peternak puyuh dalam rangka meningkatkan kesejahteraannya dan juga para peternak tersebut dapat membuang limbah dengan ada penanganannya yang tidak mencemari lingkungan Desa Gajahan sekitar.

\section{METODE PELAKSANAAN}

Dalam melaksanakan kegiatan pemberdayaan peternak berbasis sistem pengelolaan limbah terpadu, mandiri dan produktif ini, pelaksana akan membagi menjadi beberapa tahapan kegiatan, yaitu :

1. Tahapan pertama

Pendekatan dan sosialisasi sistem pengelolaan limbah kepada para peternak, di Dusun Gajahan Desa Gajahan melalui pengajian rutin dan rapat rutin $\mathrm{RT} / \mathrm{RW}$.

2. Tahap kedua

Melakukan pelatihan secara langsung kepada para peternak sebagai pelaksana tentang pelaksanaan sistem pengolahan limbah terpadu dan mandiri, dimulai pelatihan dan pembimbingan pembuangan limbah sampai pembuatan produk pupuk kompos berbahan baku kotoran puyuh. 
3. Tahap ketiga

Pembimbingan dan pendampingan peternak untuk mengaplikasikan sistem pengelolaan limbah tepadu, mandiri dan produktif. Pada tahap ini peternak didampingi ketika mereka membuat produk kompos/pupuk organik dari limbah ternak puyuh.

4. Tahap kelima

Evaluasi dan monitoring untuk mengoptimalkan pengelolaan limbah secara benar dan bernilai produktif.

\section{HASIL DAN PEMBAHASAN}

Pengabdian masyarakat dengan menggunakan metode pelatihan dan pendampingan interaktif ini diharapkan dapat memberikan pemahaman kepada para peternak puyuh dalam mengelola limbah puyuh agar supaya menjadi produk yang lebih bermanfaat, yaitu produk pupuk organik. Dengan memahami mengelola limbah puyuh dengan manajemen terpadu, limbah yang semula tidak bermanfaat di buang di selokan desa atau pinggiran sawah, maka limbah tersebut menjadi produk yang lebih bermanfaat, yaitu produk pupuk organik.

Proses produksi pupuk organik tersebut dengan melalui tahapan-tahapan antara lain:

1. Menyediakan bahan baku pupuk organik antara lain:
a. Kotoran puyuh $800 \mathrm{~kg}$,
b. Sisa-sisa tanaman/nabati
c. Dedak halus $100 \mathrm{~kg}$
d. lumpur/tanah,
e. air dan
f. decomposer/ aktifator..

2. Menyediakan alat-alat proses produksi pupuk organik, antara lain: gembor atau hand sprayer, ember/bak air, cangkul atau gancu, plastik penutup, plastik sak dan gelas ukur.
3. Memilih tempat proses produksi dalam hal ini bisa didalam ruangan atau diluar ruangan, tidak kehujanan atau sengatan matahari dan di atas tanah atau lantai.

4. Proses permentasi, antara lain:

a. Langkah pertama larutkan decompuser/aktifator dengan air dengan konsentrasi $5 \mathrm{cc} / \mathrm{liter}$ air, di dalam ember kemudian kotoran puyuh ditebar setinggi $20 \mathrm{~cm}$ di atas lantai tanah.

b. Menyiram larutan decomposer/ aktifator dengan gembor atau hand sprayer secara merata.

c. Diatas kotoran puyuh ditebarkan hijauan/ jerami dan bahan lain yang menambah nutrisi atau pestisida alam setinggi $20 \mathrm{~cm}$, kemudian disiram larutan decomposer/ aktifator secara merata. Demikian seterusnya sampai mencapai ketinggian 1 meter.

d. Kemudian lapisan kotoran puyuh dan hijauan tersebut di tutup dibagian atasnya dengan plastik atau mulsa bekas.

e. Setelah 7 hari diperiksa timperaturnya, kalo terlalu panas harus diaduk, kemudian ditutup kembali.

f. Setelah 20-25 hari kompos tersebut sudah dapat diaplikasikan. Kalau menggunakan decomposer Beka 1 liter dan Beka untuk 3-5 ton pupuk kandang/hijauan.

Dari memahami proses manajemen limbah puyuh terpadu dengan menggunakan tehnologi permentasi, maka peternak dapat membuat produksi pupuk organik. Pemahaman manajemen terpadu terhadap kegiatan pengelolaan limbah puyuh yang terarah sehingga terjadi perbaikan pengelolaan limbah puyuh yaitu mulai bagaimana merencanakan kegiatan produksi, keuangan, pemasaran hingga SDM.

Sebelum pengabdian ini di laksanakan, para peternak pada umumnya. 
1. membuang kotoran puyuh di sembarang tempat misalnya diselokan, sungai kecil, pinggiran sawah;

2. tempat penampungan kotoran puyuh berukuran kecil, tidak menampung dan berceceran, sehingga menimbulkan bau tidak sedap ketika terkena air hujan dan tertiup angin kearah perumahan warga;

3. belum dibentuk organisasi pengolah limbah puyuh, yang akan mengelola limbah puyuh menjadi produk pupuk organik yang bermanfaat.

Setelah pengabdian ini di laksanakan, maka dari hasil pemantauan para peternak dapat.

1. membuang kotoran puyuh pada tempat yang telah disediakan (Gudang kotoran puyuh) di pojok desa Gajahan;

2. tempat penampungan kotoran puyuh berukuran kecil, mulai diperbesar sehingga dapat menampung lebih banyak dan tidak berceceran, sehingga menimbulkan bau tidak sedap tidak dirasakan warga, meskipun terkena air hujan dan tertiup angin kearah perumahan warga;

3. sudah dibentuk organisasi pengolah limbah puyuh, yang akan mengelola limbah puyuh menjadi produk pupuk organik yang bermanfaat. Organisasi tersebut beranggotakan seorang ketua, sekertaris dan bendahara dibantu dua orang pembantu. Perinciannya sebagai berikut:
a. Ketua
: Bp. Mahmud Deliar
b. Sekretaris
: Bp. Agus Sutardi
c. Bendahara
: Bp. Widodo
d. Pengolahan
: Bp. Bambang S.
e. Pemasaran
: Bp. Sutiyo
f. Keuangan
: Bp. Paryono

4. Sebagian peternak secara mandiri sudah membuat produk pupuk organik meskipun untuk kebutuhan sendiri. Sementara untuk pembuatan pupuk organik bersama yang dikelola kelompok peternak belum di jalankan, hanya sudah di bentuk organisasi, sebagaimana keterangan sebelumnya.

\section{SIMPULAN DAN SARAN}

\section{SIMPULAN}

Dari pelaksanaan pengabdian ini dapat disimpulkan bahwa pengabdian dalam bentuk pelatihan dan pendampingan proses produksi pada para peternak puyuh dalam mengelola limbah puyuh agar supaya menjadi produk pupuk organik menjadi sangat penting. Dalam pelaksanaan pengabdian ini secara umum mendapat respon yang baik dari para peternak yang sangat antusias terhadap pelatihan ini. Kegiatan pengabdian ini dilanjutkan pemantauan proses produksi, agar proses produksi pupuk organik bisa lancar menghasilkan pupuk organik yang bermutu. Para peternak berharap kedepan dilanjutkan pelatihan dan pendampingan pemasaran dan pengelolaan keuangan sehingga dalam mengelola produk pupuk organik dapat terjual dan di diminati konsumen.

\section{SARAN}

Dari pengabdian ini dapat disarankan sebagai berikut :

a. Pengabdian ini perlu dilanjutkan lagi dengan pemantauan terhadap pemantauan proses produksi, agar proses produksi pupuk organik bisa lancar menghasilkan pupuk organik yang berkualitas.

b. Perlu ditindak lanjuti dengan pelatihan pengelolaan (manajemen) marketing dan pengelolaan (manajemen) keuangan sebagai upaya untuk memberdayakan peternak, sehinga peteernak dapat lebih berkembang, maju dan profesional.

\section{PERSANTUNAN}

Kegiatan pengabdian ini tidak mungkin dapat terlaksana tanpa adanya bantuan atau kerjasama yang baik dengan 
beberapa pihak. Dengan selesainya kegiatan ini, maka kami tim pengabdian mengucapkan terimaksaih kepada:

1. Rektor Universitas Muhammadiyah Surakarta yang telah memberi ijin dan fasilitas untuk kegiatan ini.

2. Ketua Lembaga Penelitian dan Pengabdian pada Masyarakat (LPPM) UMS yang telah memberikan motivasi dan bimbingan untuk melaksanakan pengabdian ini.
3. Para Pengurus atau perangkat Desa Gajahan Kecamatan Colomadu kabupaten Karanganyar yang telah memberikan ijin dan kerjasama dalam pengabdian ini.

4. Para peternak di dusun Ginung RW II Desa Gajahan Kecamatan Colomadu kabupaten Karanganyar yang telah bersedia kerjasama dalam pengabdian ini.

\section{DAFTAR PUSTAKA}

Bradley, S.J Hausman dan R. Nolan (1993), Globalization Technology and Competitions : The Fussions of Computers and Telecomunications in the 1990s, Boston Harvad Business School

Fandy Tjiptono, 1997, Strategi Pemasaran, Penerbit ANDI, Yogyakarta

Keat dan Young, 2003, Managerial Economics, Economic Tools for today's Decision Makers, Prentice Hall. Incorporation, USA

Suara Merdeka, 2009, Petani Membuang Limbah Kotoran Sapi di Sekitar Persawahan”, Harian Suara Merdeka, Semarang jateng

Kotler, P, 1994, Marketing Management : Analysis, Planning, Implementation and Control, Prentice Hall Inc. New jersey, USA

Kotler, P and G. Amstrong, 1994, Principle of Marketing, Prentice Hall Inc. New Jersey, USA Lukman Hakim, 2014, Dasar-dasar Manajemen, Penerbit Jasmine Kartasura, Surakarta

Minzberg, H, JB Quin dan J. Voyer, 1995, The Strategy process, Collegiate Edition, Prentice Hall Incorporaion, USA

Porter, ME, 1980, Competitive Strategy, Tehniqi, by Analyzing Industries and Competitors, The Free Press, New York, USA

Porter, ME, 1985, Competitive Advantage, The Free Press, New York, USA

Stanton, W, dan walker, 1994, Fundamental of Marketing, Mc Graw Hill Book Company, USA

Subhas C. Jain,1999, Marketing, planning \& Strategy, DPS Associates, Inc. , USA

Wikipedia ,2008 , Sukoharjo Dalam Potret, Wikimedia Foundation, Inc. 14 Februari 2008.

Yip, GS (1995), The Global Strategy : Managing For Word Wide Competitive Advantage, Englewood Clifft, Prentice Hall Incorporation, USA 